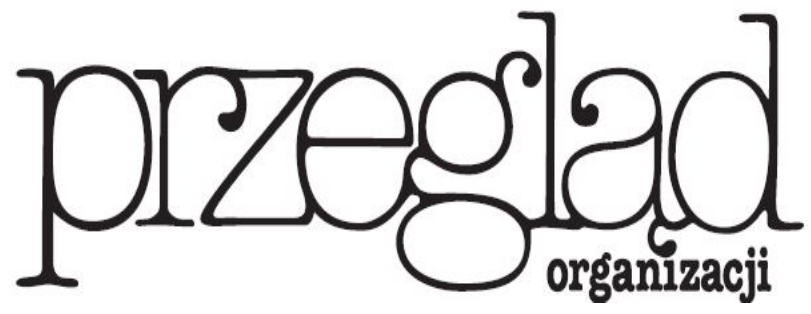

Miesięcznik TNOiK

Założył Karol Adamiecki w 1926 r.

\title{
SPOSOBY ROZWOJU PRZEDSIĘBIORSTW W SEKTORACH WYSOKIEJ I NISKIEJ TECHNIKI
}

https://doi.org/10.33141/po.2019.04.06

\section{Krzysztof Melnarowicz}

\section{Wprowadzenie}

W literaturze światowej i polskiej prezentowane są liczne badania strategii przedsiębiorstw w sektorach wysokiej techniki oraz kreatywnych. Niezwykle rzadko natomiast pojawiają się badania porównujące strategie rozwoju czy strategie konkurencji przedsiębiorstw ze względu na poziom techniki sektorów, w których działają. Można przecież zauważyć, że sukcesy przedsiębiorstw nie są jednoznacznie skorelowane $\mathrm{z}$ poziomem techniki sektora. Pokazują to liczne rankingi największych, najszybciej rozwijających się, najbardziej rentownych i najbardziej innowacyjnych przedsiębiorstw. $Z$ tego też powodu ciekawe wydaje się szukanie odpowiedzi na pytanie, w jaki sposób przedsiębiorstwa rekompensują sobie ograniczenia wynikające z przynależności do sektora niskiej techniki i za pomocą jakich strategii zapewniają sobie przewagę konkurencyjną oraz rozwój przedsiębiorstwa. W tym celu zespół badawczy ${ }^{1}$ podjął się badania celem zarejestrowania i analizy wyborów strategicznych przedsiębiorstw $\mathrm{w}$ wymiarach strategii, takich jak postrzeganie otoczenia, cele strategiczne, strategie rozwoju, sposoby rozwoju czy strategie konkurencji. Celem niniejszej publikacji jest porównanie wyborów strategicznych przedsiębiorstw z sektorów o różnym poziomie techniki i weryfikacja hipotezy mówiącej o istotnych różnicach w sposobach rozwoju stosowanych przez przedsiębiorstwa działające w sektorach niskiej i wysokiej techniki. Cel ten zostanie zrealizowany poprzez zaprezentowanie wyników oraz wniosków z przeprowadzonych badań. Dodatkowym, pobocznym aspek-
Przegląd Organizacji, Nr 4 (951), 2019, ss. 39-45 www.przegladorganizacji.pl CTowarzystwo Naukowe Organizacji i Kierownictwa (TNOiK) tem, który został odnotowany w trakcie badania, a został również zarejestrowany i przedstawiony w niniejszej publikacji, jest sposób rozwoju przedsiębiorstw ze względu na rodzaj prowadzonej działalności (przemysł/usługi).

\section{Sposoby rozwoju przedsiębiorstw w różnych poziomach techniki - przegląd literatury}

W literaturze krajowej, jak też światowej można znaleźć liczne badania $\mathrm{z}$ obszaru strategii rozwoju przedsiębiorstw w sektorach wysokiej techniki oraz w sektorach kreatywnych. I tak podjęto się próby sformułowania listy czynników sukcesu dla przedsiębiorstw sektora wysokich technologii (Braguinsky i in., 2012, s. 898) czy też próby zdefiniowania oraz ich wpływu na innowacyjność przedsiębiorstw (Melnarowicz, 2017a, s. 121). Zbadano również przedsiębiorstwa wysokiej technologii z punktu widzenia wykorzystywania przez nie technologii z branż pokrewnych (Herstad, 2018, s. 396-420).

Kluczowe znaczenie dla rozwoju przedsiębiorstw z sektora wysokiej techniki ma strategia umiędzynarodowienia. Problem internacjonalizacji przedsiębiorstw $\mathrm{z}$ tego sektora został wnikliwie przebadany oraz opisany przez wielu badaczy. Przebadano zależność umiędzynarodowienia przedsiębiorstw z sektora wysokich technologii ze sposobami ich rozwoju (Melnarowicz, 2017b, s. 16-20) czy też internacjonalizacji tych przedsiębiorstw i pozyskania nowych źródeł 
wiedzy (Wach, 2016). Również z badań przeprowadzonych przez Komisję Europejską można wnioskować, że przedsiębiorstwa wysokiej techniki wybierają bardziej zaawansowane strategie i formy internacjonalizacji w porównaniu z przedsiębiorstwami niskiej techniki, a ich internacjonalizacja przebiega szybciej oraz jest na wcześniejszym etapie rozwoju niż przedsiębiorstw $\mathrm{z}$ sektora niskiej techniki (Observatory, 2003, s. 28). Sposób rozwoju zewnętrznego może być poprzedzony czy też wspomagany przez różne formy współpracy $\mathrm{z}$ kooperantami czy konkurentami. Istotna zatem wydaje się nowoczesna czy sieciowa forma współpracy (klastry, wspólne konsorcja i projekty, licencje czy franczyzy), która może wpłynąć w późniejszym etapie życia przedsiębiorstwa na jego zewnętrzny lub wewnętrzny sposób rozwoju. W literaturze opisano także strategie rozwoju przedsiębiorstw z poszczególnych branż poprzez współpracę w ramach aliansów (Sroka, 2012, s. 172). Wskazano, że alianse mają znaczny wpływ na to, w jaki sposób rozwijają się przedsiębiorstwa. Również kooperacja $\mathrm{z}$ konkurentami polskich przedsiębiorstw wysokiej techniki została przebadana przez PARP w 2015 roku (Zadura-Lichota, 2015, s. 28), porównująca Polskę z innymi krajami UE. I tak, $\mathrm{w}$ naszym kraju wykazano niższy odsetek innowacyjnych przedsiębiorstw kooperujących $\mathrm{z}$ konkurentami $(7 \%)$ niż średnia zbadanych w 28 krajach UE (9\%).

W innych badaniach przeanalizowano aktywność i możliwości rozwoju sektora wysokiej technologii w części branż kreatywnych w Polsce w porównaniu z Unią Europejską (Ratalewska, 2016, s. 57-67). Wykazano $w$ tych badaniach, że w Polsce współpraca między firmami z branży kreatywnej przybiera wiele form - od stosunkowo prostej (udział w targach), poprzez projekty badawczo-rozwojowe, po współpracę przy tworzeniu wspólnych koncepcji marketingowych związanych $\mathrm{z}$ wprowadzeniem na rynek. Porównano same sektory wysokiej techniki w różnych krajach oraz wpływ profilu specjalizacji tych krajów na rozwój ich przedsiębiorstw (Boix i in., 2016, s. 935-940).

Sposoby rozwoju przedsiębiorstw były również badane pod kątem dywersyfikacji działalności przedsiębiorstw (Jakubowska, 2012). Badanie było przeprowadzone na szerokiej grupie przedsiębiorstw wysokiej i niskiej techniki. Na przykładzie polskich grup kapitałowych nie wykryto zależności między sposobem rozwoju przedsiębiorstw a dywersyfikacją, jej poziomem oraz charakterem.

Rozwój przedsiębiorstw został również przeanalizowany pod innym kątem. Zbadano wątek związku rozwoju przedsiębiorstw wszystkich poziomów techniki $\mathrm{z}$ uwarunkowaniami zasobowymi. W badaniu tym przyjęto, że sprawne i efektywne wykorzystanie zasobów wymaga ich szybkiego akumulowania, umiejętnej koncentracji, łączenia i koordynacji (Skowronek-Mielczarek, 2013, s. 6). $\mathrm{W}$ badaniach tych jednak, podobnie jak we wcześniej wymienionych, zauważalne jest pominięcie różnic międzysektorowych, które mogły dać inne wyniki niż w badaniu zawierającym wszystkie poziomy techniki.

Pojawiają się też badania i analizy dotyczące rozwoju przedsiębiorstw $\mathrm{w}$ sektorze niskiej techniki. Na przykład sposoby rozwoju przedsiębiorstw były analizowane w przemyśle meblarskim (Dyba, Stryjakiewicz, 2014). Przedstawiano inicjatywę klastrową jako szanse i sposób na rozwój małych i średnich przedsiębiorstw przemysłu meblarskiego w Polsce. Niemniej znowu można zauważyć brak badania porównującego związki inicjatywy klastrowej jako nowoczesnej/sieciowej formy współpracy $\mathrm{z}$ poziomami techniki przedsiębiorstw. Badane również były determinanty rozwoju przedsiębiorstw sektora rolno-spożywczego (Firlej, 2008). Głównym celem tej rozprawy była analiza i ocena rozwoju przedsiębiorstw tego sektora oraz przedstawienie czynników ograniczających jego funkcjonowanie.

Ciekawa analiza dotycząca wyboru strategii rozwojowej wraz z określeniem rekomendacji pojawiła się w obszarze przedsiębiorstw przemysłowych (Janasz, 2016, s. 29-34). Analiza ta była jednak sprofilowana na zachowania i funkcjonowanie konkurencji, stosowanie technologii przemysłowej oraz możliwości finansowe przedsiębiorstw, ale nie obejmowała sposobów rozwoju.

Krótka analiza dostępnych badań oraz literatury z obszaru rozwoju przedsiębiorstw wykazała, że istnieje szereg badań i analiz dotyczących sposobu rozwoju przedsiębiorstw $\mathrm{w}$ poszczególnych poziomach techniki, tzn. albo we wszystkich poziomach techniki lub alternatywnie w niskiej lub wysokiej technice. Brakuje jednak badań dotyczących zależności zachowań przedsiębiorstw, a zwłaszcza sposobów ich rozwoju, form, determinant czy zakresu współpracy w zależności od poziomu techniki. Ta luka badawcza została po części wypełniona przedstawionymi w niniejszym artykule badaniami, a ich wyniki mogą posłużyć do ciekawych zestawień oraz dalszych badań i analiz z innymi wymiarami strategii przedsiębiorstw.

\section{Zakres i metodyka badań}

W publikacji zostały przedstawione wyniki badań empirycznych przeprowadzonych $w$ ramach badań statutowych Kolegium Zarządzania i Finansów SGH w Warszawie pt. „Strategie przedsiębiorstw w sektorach wysokiej i niskiej techniki - analiza porównawcza" w części dotyczącej sposobu rozwoju przedsiębiorstw. Celem całych badań było znalezienie odpowiedzi na pytanie, czy $\mathrm{w}$ polskich przedsiębiorstwach występują opisane w literaturze różnice $\mathrm{w}$ wyborach strategicznych związane $\mathrm{z}$ ich przynależnością do sektorów wysokiej lub niskiej techniki. Badaniami objęto następujące wątki tematyczne: strategie rozwoju i konkurencji, modele biznesowe, sposoby rozwoju, kulturę organizacyjną i przywództwo. W niniejszym opracowaniu zostaną zaprezentowane wyniki dotyczące sposobu rozwoju przedsiębiorstw.

Badania empiryczne przeprowadzono w maju i czerwcu 2018 roku na próbie 85 polskich przedsiębiorstw $\mathrm{z}$ „Listy 2000" opublikowanej w 2017 roku. Na liście tej znajduje się 2000 przedsiębiorstw o najwyższych przychodach ze sprzedaży zrealizowanej w 2016 roku. Wszystkie przedsiębiorstwa z „Listy 2000” zostały zaklasyfikowane przez badaczy, zgodnie z kryteriami poziomu techniki głównego sektora ich działalności. Prawie 25\% przedsiębiorstw z „Listy 2000” nie zostało zakwalifikowanych do żadnej kategorii pozio- 
mu techniki (klasyfikacja ta nie obejmuje np. działalności rolniczej i wydobywczej). Dodatkowo dołączono do poziomów techniki wyodrębniony w Eurostat sektor ICT, sklasyfikowany w oparciu o definicję OECD. Definicja sektora ICT, która bazuje na Statystycznej Klasyfikacji Działalności Gospodarczej Unii Europejskiej NACE² obejmuje przedsiębiorstwa, które umożliwiają elektroniczne przetwarzanie informacji i komunikację (łącznie $\mathrm{z}$ transmisją i wyświetlaniem), oraz przedsiębiorstwa, które zajmują się świadczeniem takich usług, które umożliwiają elektroniczne przetwarzanie informacji i komunikację.

Spośród ponad 1500 przedsiębiorstw zakwalifikowanych do kategorii poziomu techniki oraz wytypowanych do badań, na badanie ankietowe odpowiedziało 85 przedsiębiorstw (5,6\%). W tabeli 1 przedstawiono strukturę wylosowanych do badań przedsiębiorstw i strukturę całej zbiorowości przedsiębiorstw z „Listy 2000”.

Badania przeprowadzono metodą CATI we współpracy z firmą Norstat Polska sp. z o.o. Kwestionariusz opracowanej ankiety zawierał 23 pytania podstawowe oraz metryczkę (m.in. formę własności, PKD, aktywa, kapitał własny, zatrudnienie, ROE, ROA, ROS), a respondentami byli przedstawiciele kierownictwa przedsiębiorstw. Zamiarem badaczy było porównanie odpowiedzi na pytania przedstawicieli przedsiębiorstw wysokiej techniki i usług wiedzochłonnych $\mathrm{z}$ pozostałymi przedsiębiorstwami i w ten sposób zdiagnozowanie ich odmienności. Badając sposoby rozwoju przedsiębiorstw, pierwszy problem badawczy dotyczył form rozwoju przedsiębiorstw stosowanych w ciągu ostatnich pięciu lat. W trakcie badania część przedsiębiorstw deklarowała kilka form rozwoju, stąd liczba uzyskanych odpowiedzi była większa od jedności. Aby pokazać dwa różne sposoby rozwoju przedsiębiorstw, autor podzielił odpowiedzi na dwa sposoby rozwoju przedsiębiorstw: rozwój wewnętrzny oraz zewnętrzny.
Kolejnym obszarem, który zbadano w ramach sposobów rozwoju przedsiębiorstw, były formy współpracy z kooperantami oraz konkurentami. Badacz poszukiwał tutaj przedsiębiorstw ze względu na poziom techniki oraz rodzaj działalności, które współdziałały w postaci nowoczesnych form współpracy (np. sieciowych) oraz tradycyjnie (współpraca niesieciowa, np. na podstawie umów). Badając sposoby rozwoju przedsiębiorstw, postanowiono również ocenić, jak wygląda ich zakres współpracy z konkurentami w zależności od poziomu techniki sektora działalności.

\section{Rozwój przedsiębiorstw z perspektywy wysokiej i niskiej techniki - wyniki badań}

D ylemat przedsiębiorstw, rozwijać się poprzez gromadzenie zasobów niezbędnych do dalszego rozwoju czy przejęcie innego przedsiębiorstwa, zawsze pozostaje czymś problematycznym. Naturalnie wybór ten również bywa wypadkową poziomu czy etapu rozwoju podmiotów gospodarczych. Nie zostało nigdzie zbadane, jak poziom techniki przedsiębiorstw wpływa na sposób ich rozwoju, stąd postanowiono podzielić przedsiębiorstwa usługowe i przemysłowe na niski i wysoki poziom techniki oraz sprawdzić, jak ta zależność wygląda w polskich przedsiębiorstwach. W tym celu zostało zadane w badaniu pytanie dotyczące form rozwoju przedsiębiorstw, które można podzielić na wewnętrzne (rozbudowa i unowocześnienie posiadanego potencjału, budowa nowych obiektów) i zewnętrzne (przejmowanie innych przedsiębiorstw, tworzenie spółek i łączenie się z innymi przedsiębiorstwami). Zarówno procentowy udział odpowiedzi, jak i wyników badań został zaprezentowany w tabeli 2.

Tabela 1. Struktura przedsiębiorstw z „Listy 2000” i struktura badanych przedsiębiorstw z punktu widzenia poziomu techniki sektora dziatalności

\begin{tabular}{|c|c|c|c|c|}
\hline \multirow{2}{*}{$\begin{array}{l}\text { Rodzaje przedsiębiorstw ze } \\
\text { względu na poziom techniki }\end{array}$} & \multicolumn{2}{|c|}{ Liczba przedsiębiorstw } & \multicolumn{2}{|c|}{ Udział przedsiębiorstw w grupie (\%) } \\
\hline & z Listy 2000 & zbadanych & z Listy 2000 & zbadanych \\
\hline \multicolumn{5}{|c|}{ Grupa: produkcja } \\
\hline Wysoka technika & 42 & 4 & 6 & 8 \\
\hline Średnio-wysoka technika & 153 & 11 & 21 & 22 \\
\hline Średnio-niska technika & 227 & 22 & 31 & 44 \\
\hline Niska technika & 303 & 13 & 42 & 26 \\
\hline Razem & 725 & 50 & 100 & 100 \\
\hline \multicolumn{5}{|c|}{ Grupa: usługi } \\
\hline Usługi oparte na wiedzy & 214 & 7 & 27 & 20 \\
\hline Usługi mniej wiedzochłonne & 576 & 28 & 73 & 80 \\
\hline Razem & 780 & 35 & 100 & 100 \\
\hline Niesklasyfikowane & 495 & - & 25 & - \\
\hline Razem wszystkie & 2000 & 85 & & \\
\hline
\end{tabular}

Źródło: opracowanie własne 
Wprawdzie liczba przedsiębiorstw w poszczególnych poziomach techniki nie była równa, niemniej z badania można wychwycić pewne ciekawe wyniki oraz prawidłowości. Wyraźnie widać, że w każdym z badanych poziomów techniki większa część przedsiębiorstw rozwija się w sposób wewnętrzny, tzn. poprzez rozbudowę i unowocześnienie posiadanego potencjału oraz budowę nowych obiektów. Zauważalne jest jednak, że spółki z wysokiej techniki znacznie chętniej stosowały sposoby rozwoju zewnętrznego. $\mathrm{Z}$ przebadanych przedsiębiorstw wynika bowiem, że 31\% odpowiedzi z przedsiębiorstw niskiej techniki wskazało na rozwój w sposób zewnętrzny, podczas gdy ponad prawie dwukrotnie więcej (64\%) odpowiedzi (zakładając oczywiście mniejszą liczbę badanych) wskazały przedsiębiorstwa $\mathrm{z}$ wysokiej techniki. Badanie to potwierdza tezę, stawianą przez badaczy (Melnarowicz, 2017b, s. 20), że przedsiębiorstwa wysokiej techniki budują chętniej swoją przewagę konkurencyjną oraz innowacyjność poprzez rozwój zewnętrzny aniżeli przedsiębiorstwa niskiej techniki. Badanie to może również sugerować związek innowacyjności oraz sposobu rozwoju przedsiębiorstw. Literatura, jak też praktyka wskazują bowiem, że przedsiębiorstwa $\mathrm{z}$ wysokiej techniki są znacznie bardziej zmuszane przez szeroko pojęty rynek czy też bezpośrednio swoją konkurencję do szybszego poszukiwania innowacyjności oraz jak najszybszego ich wdrażania aniżeli podmioty niskiej techniki. Zostało to również potwierdzone badaniami prowadzonymi na przedsiębiorstwach wysokiej techniki (Melnarowicz, 2017b, s. 17-20). Efektem dodatkowym badań było uzyskanie wyników ze względu na rodzaj prowadzonej działalności (przemysł i usługi). Wyniki jednak, biorąc pod uwagę sposoby rozwoju przedsiębiorstw, różnią się tylko nieznacznie (przedsiębiorstwa usługowe nieco częściej wybierały rozwój zewnętrzny niż przemysłowe). Wydają się one zatem w tym przypadku niewystarczające, aby stwierdzić jakąś zdecydowaną prawidłowość, co można już dostrzec w przypadku poziomu techniki.

Następnymi pytaniami ankietowymi zadanymi przez badacza przedsiębiorstwom były pytania związane z formą współpracy z kooperantami oraz konkurentami. Zadanie ich miało na celu zbadanie przedsiębiorstw z punktu widzenia ich rozwoju w kierunku nowoczesnych (sieciowych) lub tradycyjnych (niesieciowych) form współpracy. Nowoczesne/sieciowe formy współpracy zostały przyjęte jako umowy licencyjne i franczy-

Tabela 2. Formy rozwoju przedsiębiorstw w zależności od poziomu techniki i rodzaju dziatalności

\begin{tabular}{|c|c|c|c|c|c|}
\hline & \multirow[b]{3}{*}{ RAZEM } & \multirow{2}{*}{\multicolumn{2}{|c|}{ Poziom techniki }} & & \\
\hline & & & & \multicolumn{2}{|c|}{ Rodzaj działalności } \\
\hline & & Niska technika & Wysoka technika & Przemyst & Usługi \\
\hline Formy rozwoju & 85 & 63 & 22 & 50 & 35 \\
\hline Rozbudowa i unowocześnianie posiadanego potencjału & $86 \%$ & $84 \%$ & $91 \%$ & $88 \%$ & $83 \%$ \\
\hline Budowa nowych obiektów & $58 \%$ & $54 \%$ & $68 \%$ & $70 \%$ & $40 \%$ \\
\hline Przejmowanie innych przedsiębiorstw w całości lub części & $26 \%$ & $21 \%$ & $41 \%$ & $26 \%$ & $26 \%$ \\
\hline Tworzenie spółek z innymi przedsiębiorstwami & $9 \%$ & $8 \%$ & $14 \%$ & $8 \%$ & $11 \%$ \\
\hline Łączenie się z innymi przedsiębiorstwami & $4 \%$ & $2 \%$ & $9 \%$ & $4 \%$ & $3 \%$ \\
\hline Inne, jakie? & $8 \%$ & $10 \%$ & $5 \%$ & $6 \%$ & $11 \%$ \\
\hline Nie wiem/trudno powiedzieć & $4 \%$ & $5 \%$ & - & $2 \%$ & $6 \%$ \\
\hline
\end{tabular}

Źródto: opracowanie własne na podstawie badań zleconych Norstat

Tabela 3. Formy wspótpracy z kooperantami

\begin{tabular}{|c|c|c|c|c|c|}
\hline & \multirow[b]{2}{*}{ RAZEM } & \multicolumn{2}{|c|}{ Poziom techniki } & \multicolumn{2}{|c|}{ Rodzaj działalności } \\
\hline & & Niska technika & Wysoka technika & Przemyst & Usługi \\
\hline Formy współpracy z kooperantami & 85 & 63 & 22 & 50 & 35 \\
\hline Umowy krótkookresowe & $60 \%$ & $60 \%$ & $59 \%$ & $68 \%$ & $49 \%$ \\
\hline Umowy długookresowe & $86 \%$ & $87 \%$ & $82 \%$ & $90 \%$ & $80 \%$ \\
\hline Umowy licencyjne i franczyzowe & $18 \%$ & $14 \%$ & $27 \%$ & $12 \%$ & $26 \%$ \\
\hline Wspólne projekty i konsorcja & $25 \%$ & $22 \%$ & $32 \%$ & $30 \%$ & $17 \%$ \\
\hline Udział w klastrach & $7 \%$ & $6 \%$ & $9 \%$ & $8 \%$ & $6 \%$ \\
\hline Współpraca w ramach grupy kapitałowej & $51 \%$ & $46 \%$ & $64 \%$ & $52 \%$ & $49 \%$ \\
\hline Inne, jakie? & $2 \%$ & $2 \%$ & $5 \%$ & - & $6 \%$ \\
\hline Nie wiem/trudno powiedzieć & $4 \%$ & $5 \%$ & - & $6 \%$ & - \\
\hline
\end{tabular}

Źródto: opracowanie wtasne na podstawie badań zleconych Norstat 
zowe, wspólne projekty i konsorcja, udział/współpraca w klastrach, współpraca w ramach grupy kapitałowej czy spółki typu joint venture. Do tradycyjnych form współpracy badacz zaliczył tradycyjne umowy o charakterze krótko - i długoterminowym. Wyniki badania ankietowego dotyczącego form współpracy z kooperantami zostały zaprezentowane w tabeli 3 .

Z otrzymanych odpowiedzi można stwierdzić, że przedsiębiorstwa wysokiej techniki częściej biorą udział w nowoczesnych formach współpracy z kooperantami. Odsetek odpowiedzi jest bowiem tutaj znacznie większy niż w przypadku niskiej techniki. Można zatem na podstawie uzyskanych odpowiedzi zarysować pewien trend sposobu rozwoju przedsiębiorstw wysokiej techniki. Oprócz rozwoju zewnętrznego, przedsiębiorstwa $\mathrm{z}$ tego poziomu techniki są również bardziej otwarte na nowoczesną współpracę. W przypadku tego pytania, jak $\mathrm{w}$ poprzednim pytaniu, nie zauważono także znaczącej różnicy w podejściu do form współpracy przy rodzaju działalności (usługi/przemysł). W przypadku pytania dotyczącego form współpracy z konkurentami wyniki badań okazały się całkiem podobne, co przedstawia tabela 4 .
Przedsiębiorstwa wysokiej techniki również częściej opowiadały się za nowoczesnymi formami współpracy z konkurentami. W tym przypadku przewaga odpowiedzi po stronie wysokiej techniki okazała się nawet większa niż w przypadku kooperantów, bo prawie dwukrotna ( $27 \%$ niska technika vs. $50 \%$ wysoka technika). Może to oznaczać, że przedsiębiorstwa wysokiej techniki chętniej współpracują z konkurentami niż kooperantami przy nowoczesnych/sieciowych formach współpracy.

Oprócz opisanych już form współpracy z konkurentami (np. rodzajów umów, form przyjętej współpracy), ciekawe wyniki ankiety dotyczące zakresu współpracy z konkurentami (np. obszaru prowadzenia badań, wspólnej produkcji, zakupów itd.) zaprezentowano w tabeli 5.

Zakres współpracy z konkurentami wskazuje na przedsiębiorstwa wysokiej techniki jako te, które mają większą skłonność do sposobu rozwoju opartego na wiedzy i zasobach zewnętrznych. Różnice nie są już tak jednak wyraźne, jeśli porówna się rodzaje działalności. Chociaż tutaj badania wskazują na nieco większą skłonność do sieciowego zakresu współpracy w kierunku przedsiębiorstw przemysłowych.

\section{Tabela 4. Formy współpracy z konkurentami}

\begin{tabular}{|c|c|c|c|c|c|}
\hline & \multirow[b]{2}{*}{ RAZEM } & \multicolumn{2}{|c|}{ Poziom techniki } & \multicolumn{2}{|c|}{ Rodzaj działalności } \\
\hline & & Niska technika & Wysoka technika & Przemyst & Usługi \\
\hline Formy współpracy z konkurentami & 85 & 63 & 22 & 50 & 35 \\
\hline Umowy o współpracy & $28 \%$ & $30 \%$ & $23 \%$ & $22 \%$ & $37 \%$ \\
\hline Umowy licencyjne i franczyzowe & $5 \%$ & $3 \%$ & $9 \%$ & $2 \%$ & $9 \%$ \\
\hline Wspólne projekty & $17 \%$ & $16 \%$ & $18 \%$ & $14 \%$ & $20 \%$ \\
\hline Spółki typu joint venture & $5 \%$ & $3 \%$ & $9 \%$ & $6 \%$ & $3 \%$ \\
\hline Współpraca w klastrach & $7 \%$ & $5 \%$ & $14 \%$ & $8 \%$ & $6 \%$ \\
\hline Inne, jakie? & $14 \%$ & $16 \%$ & $9 \%$ & $18 \%$ & $9 \%$ \\
\hline Nie wiem/trudno powiedzieć & $44 \%$ & $41 \%$ & $50 \%$ & $48 \%$ & $37 \%$ \\
\hline
\end{tabular}

Źródto: opracowanie własne na podstawie badań zleconych Norstat

Tabela 5. Zakres wspótpracy z konkurentami

\begin{tabular}{|l|c|c|c|c|c|}
\cline { 3 - 6 } \multicolumn{2}{c|}{} & \multicolumn{2}{c|}{ Poziom techniki } & \multicolumn{2}{c|}{ Rodzaj działalności } \\
\cline { 2 - 6 } \multicolumn{1}{c|}{} & RAZEM & Niska technika & Wysoka technika & Przemyst & Usługi \\
\hline Zakres współpracy z konkurentami & $\mathbf{8 5}$ & $\mathbf{6 3}$ & $\mathbf{2 2}$ & $\mathbf{5 0}$ & $\mathbf{3 5}$ \\
\hline Wspólne prowadzenie B+R & $2 \%$ & $2 \%$ & $5 \%$ & $4 \%$ & - \\
\hline Udostępnianie sobie zasobów & $19 \%$ & $21 \%$ & $14 \%$ & $18 \%$ & $20 \%$ \\
\hline Wspólna produkcja & $12 \%$ & $10 \%$ & $18 \%$ & $20 \%$ & - \\
\hline Wspólna dystrybucja & $15 \%$ & $14 \%$ & $18 \%$ & $12 \%$ & $20 \%$ \\
\hline Wspólne zakupy & $7 \%$ & $6 \%$ & $9 \%$ & $4 \%$ & $11 \%$ \\
\hline Współpraca w ramach klastra & $8 \%$ & $6 \%$ & $14 \%$ & $10 \%$ & $6 \%$ \\
\hline Inne?(np. lobbing) & $38 \%$ & $38 \%$ & $36 \%$ & $38 \%$ & $37 \%$ \\
\hline Nie współpracuje & $40 \%$ & $38 \%$ & $46 \%$ & $42 \%$ & $37 \%$ \\
\hline
\end{tabular}

Źródło: opracowanie własne na podstawie badań zleconych Norstat 


\section{Podsumowanie}

$\mathbf{P}$ rzeprowadzone badanie pokazuje różnice w podejściu przedsiębiorstw $\mathrm{z}$ danego poziomu techniki do sposobu rozwoju. Przy podanych formach rozwoju okazuje się, że przedsiębiorstwa wysokiej techniki znacznie częściej biorą udział $\mathrm{w}$ przejmowaniu innych przedsiębiorstw. Wskazało na to aż $41 \%$ odpowiedzi wśród 22 badanych przedsiębiorstw. Tylko $21 \%$ opowiedziało się za tą formą rozwoju wśród przedsiębiorstw niskiej techniki. Warto podkreślić, że wśród zewnętrznych sposobów rozwoju nie była to jedyna forma przeważająca. Okazuje się, że przedsiębiorstwa wysokiej techniki równie mocno różnią się od tych z niskiej techniki w innych formach zewnętrznego rozwoju, jak tworzenie spółek z innymi przedsiębiorstwami (14\% vs. $8 \%$ ) czy łączenie się z innymi podmiotami (9\% vs. 2\%). Co więcej, badania dotyczące form i zakresu współpracy pokazują dalsze zróżnicowanie przedsiębiorstw o różnych poziomach techniki. Zróżnicowanie to dotyczy nowoczesnych/sieciowych i tradycyjnych/niesieciowych form współpracy. Przedsiębiorstwa wysokiej techniki częściej w badaniu wybierały nowoczesne formy współpracy z kooperantami czy konkurentami oraz nowoczesny/sieciowy zakres współpracy. Natomiast przedsiębiorstwa niskiej techniki wybierały zdecydowanie tradycyjne formy umów (krótko- i długookresowych, o współpracy) oraz wspólną produkcję (m.in. z powodu wysokich nakładów, jakie same muszą ponosić).

Na koniec należy podkreślić, że zróżnicowanie ze względu na rodzaj działalności, tzn. pomiędzy przedsiębiorstwa przemysłowe oraz usługi, nie dały tak jednoznacznych wyników, jak w przypadku poziomów sektorów, choć pewne różnice pojawiły się w przypadku zakresu współpracy z konkurentami (usługi miały większy udział we wspólnych zakupach czy dystrybucji).

Badanie umożliwiło zatem porównanie wyborów strategicznych przedsiębiorstw o różnym poziomie techniki oraz zweryfikowało pozytywnie hipotezę dotyczącą różnicy w sposobach rozwoju stosowanych przez przedsiębiorstwa działające w sektorach niskiej i wysokiej techniki. Interpretując uzyskane wyniki, należy mieć jednak na uwadze ich ograniczenia wynikające po pierwsze $\mathrm{z}$ faktu niewielkiego zwrotu ankiet (uzyskano je jedynie z 85 przedsiębiorstw spośród 1500 wytypowanych do badania), a po drugie z zastosowanej metody badawczej (CATI). Wyniki otrzymanych badań mogą być jednak pomocne dla menedżerów przy określaniu sposobów rozwoju przedsiębiorstw w poszczególnych sektorach techniki. Pomogą one również w dalszych analizach naukowych zależności sposobu rozwoju przedsiębiorstw $\mathrm{z}$ innymi wymiarami strategii. Wiadomo już bowiem, że przedsiębiorstwa wysokiej techniki chętniej wykorzystują zewnętrzny sposób rozwoju oraz nowoczesne/sieciowe formy współpracy niż te niskiej techniki.

\section{dr Krzysztof Melnarowicz \\ Szkoła Główna Handlowa w Warszawie \\ Kolegium Zarządzania i Finansów \\ ORCID: 0000-0001-6762-1029 \\ e-mail: krzysztof.melnarowicz@sgh.waw.pl}

\section{Przypisy}

1) Skład zespołu: S. Gregorczyk, K. Melnarowicz, M. Romanowska, P. Wachowiak.

2) Polska Klasyfikacja Działalności 2007.

\section{Bibliografia}

[1] Boix R., Capone F., De Propris L., Lazzeretti L., Sanchez D. (2016), Comparing Creative Industries in Europe, „European Urban and Regional Studies”, Vol. 23, No. 4, pp. 935-940.

[2] Braguinsky S., Klepper S., Ohyama A. (2012), High-tech Entrepreneurship, „Journal of Law \& Economics”, Vol. 55, No. 4, pp. 869-900.

[3] Dyba M.W., Stryjakiewicz T. (2014), Inicjatywy klastrowe jako szansa rozwoju przemystu meblarskiego w Polsce w warunkach kryzysu - przykład Swarzędzkiego Klastra Producentów Mebli, Prace Komisji Geografii Przemysłu Polskiego Towarzystwa Geograficznego, Uniwersytet im. Adama Mickiewicza, Poznań, s. 182-196.

[4] European Commission (2003), Observatory of European SMEs, Highlights from the 2003 Observatory, Office for Official Publications of the European Communities, Luxemburg, No. 5, pp. 9-35.

[5] Firlej K. (2008), Rozwój przemysłu rolno-spożywczego $w$ sektorze agrobiznesu i jego determinanty, Wydawnictwo Uniwersytetu Ekonomicznego w Krakowie, Kraków.

[6] Herstad S.J. (2018), Beyond "Related Variety”: How Inflows of Skills Shape Innovativeness in Different Industries, „European Planning Studies", Vol. 26, No. 2, pp. 396-420.

[7] Jakubowska W. (2012), Sposoby rozwoju przedsiębiorstw zdywersyfikowanych, „Studia i Prace Kolegium Zarządzania i Finansów", Nr 118, s. 85-95.

[8] Janasz K. (2016), Dylematy wyboru strategii rozwojowych przedsiębiorstw przemysłowych, „Przegląd Organizacji”, $\mathrm{Nr} 10$, s. 29-34.

[9] Melnarowicz K. (2017), Działalność innowacyjna polskich przedsiębiorstw - przegląd narzędzi pomiaru, „Studia i Prace Kolegium Zarządzania i Finansów", Nr 158, s. 117-134.

[10] Melnarowicz K. (2017), Rozwój zewnętrzny jako czynnik wspomagajacy innowacyjność $w$ przedsiębiorstwach, „Studia i Prace Kolegium Zarządzania i Finansów”, Warszawa, Nr 156/2017, s. 9-23.

[11] Ratalewska M. (2016), The Development of Creative Industries in Poland Comparison with the European Union, Euroasian Studies in Business and Economics, „Entrepreneurship, Business and Economics”, Vol. 3-1, pp. 57-68.

[12] Skowronek-Mielczarek A. (2013), Zasobowe uwarunkowania rozwoju przedsiębiorstw $w$ Polsce, CEDEWU, Warszawa.

[13] Sroka W. (2012), Sieci Aliansów. Poszukiwanie przewagi konkurencyjnej przez wspótpracę, PWE, Warszawa.

[14] Wach K. (2016), Strategiczne myślenie w procesie internacjonalizacji polskich przedsiębiorstw, Zeszyty Naukowe Uniwersytetu Ekonomicznego w Katowicach, Nr 271, s. 28-41.

[15] Zadura-Lichota P. (2015), Innowacyjna przedsiębiorczość $w$ Polsce. Odkryty i ukryty potencjał polskiej innowacyjności, PARP, Warszawa. 


\section{Ways of Enterprise Development in High and Low Technology Sectors}

\section{Summary}

This publication present results and conclusions from empirical research in the part concerning the method of enterprise development, conducted by a team of researchers as part of the statutory research of the Collegium of Management and Finance of the Warsaw School of Economics entitled „Business strategies in the high and low technology sectors - comparative analysis". Empirical studies were conducted using the CATI method in May and June 2018 on a sample of 85 Polish companies from the „List 2000”, which was published in 2017. The entire questionnaire contained 23 questions and a metric. The respondents were representatives of enterprises management. Four questions asked were related to the development of enterprises. The intention of the researcher in this part of the research, was to compare the answers to the questions given by representatives of high technology enterprises and knowledge-intensive services with other enterprises, and thus to diagnose their differences. The research has given unequivocal results that have confirmed the hypothesis on the differences in the ways of development used by enterprises operating at different levels of technology. The results of the conducted research can be the basis for further analyses regarding the impact of the way enterprises develop on other dimensions of companies' strategies with different levels of technology.

\section{Keywords}

strategy, enterprises, management, high and low technology sectors 